\title{
ОБМЕЖЕННЯ ПРАВА ВЛАСНОСТІ ПЦД ЧАС ДОСУДОВОГО РОЗСЛІДУВАННЯ КРИМІНАЛЬНИХ ПРАВОПОРУШЕНЬ
}

\author{
КЦЦЕН Наталія Валентинівна - кандидат юридичних наук, доцент, \\ доцент кафедри кримінальної юстиції Чернівецького юридичного інституту \\ Національного університету «Одеська юридична академія» \\ DOI 10.32782/NP.2021.1.17
}

Статья посвящена раскрьттию на основе норм Уголовного процессуального кодекса Украинъ ограничений права собственности в ходе досудебного расследования уголовнъгх правонарушений.

Исследованъ сбормированнъие в доктрине уголовного прочесса определения понятия «ограничение права собственности», на основе анализа которьхх приведен авторский подход к въделению признаков, которьими оно характеризуется. Проанализированъ теоретические подходъ к определению круга следственньхх (розвискнъих) действий и мер обеспечения уголовного производства, которьие приводят к ограничению права собственности в ходе досудебного расследования. Поддержана позищия о челесообразности осуществления классификаџии оснований ограничения права собственности в ходе уголовного производства на две группъи: правовъе и бактические. С учетом норм Уголовного прочессуального кодекса Украинь раскрьтть требования к определению следственного судви как основному правовому основанию ограничения этого права в ходе досудебного расследования, указанъ случаи его постановления, а также определенъ инъие правовъие основания ограничения права собственности в этой стадии уголовного производства. Указано на зависимость Фактических оснований ограничения этого права от вида следственнъих (розъикньих) действий или мер обеспечения уголовного производства, подлежащих проведению или применению в уголовном производстве.

По результатам исследования определено понятие «ограничение права собственности»в его уголовном прочессуальном смылле, обобщенъи установленнъе законом ограничения этого права во время досудебного расследования и определено понятие правовъхх и бактических оснований его осуществления.

Ключевъе слова: приниципь уголовного производства, неприкосновенность права собственности, ограничения права собственности, досудебное расследование, постановление следственного судьи, протокол.

\section{Постановка проблеми}

Однією із загальних засад кримінального провадження є недоторканність права власності (пункт 9 частини 1 статті 7 та стаття 16 КПК України). Вказана засада грунтується на статті 41 Конституції України, яка закріплює визначальні для розкриття ії змісту в кримінальному провадженні елементи: 1) право кожного володіти, користуватися і розпоряджатися своєю власністю; 2) непорушність права власності та заборону протиправного позбавлення цього права; 3) винятковість випадків застосування примусового відчуження об’єктів права власності з мотивів суспільної необхідності, на підставі і в порядку, встановлених законом, та за умови попереднього і повного відшкодування їх вартості;4) можливість застосування конфіскації майна тільки за рішенням суду у випадках, обсязі та порядку, встановлених законом [1]. Наведені положення Конституції України у повному обсязі відповідають міжнародним стандартам забезпечення права власності, у тому числі й під час здійснення кримінального провадження. 
Так, стаття 1 Першого протоколу від 20 березня 1952 року до Конвенції про захист прав людини і основоположних свобод передбачає, що кожна фізична або юридична особа має право мирно володіти своїм майном. Нixто не може бути позбавлений своєї власності інакше як в інтересах суспільства і на умовах, передбачених законом і загальними принципами міжнародного права. Проте, попередні положення жодним чином не обмежують право держави вводити в дію такі закони, які вона вважає за необхідне, щоб здійснювати контроль за користуванням майном відповідно до загальних інтересів або для забезпечення сплати податків чи інших зборів або штрафів [2]. 3 урахуванням наведених положень, обмеження та позбавлення права власності у ході кримінального провадження може здійснюватися тільки з підстав і в порядку, встановлених законом.

Стосовно кримінального провадження підстави і порядок обмеження та позбавлення права власності в загальному визначені статтею 16 КПК України, відповідно до якої:1) позбавлення або обмеження права власності під час кримінального провадження здійснюється лише на підставі вмотивованого судового рішення, ухваленого в порядку, передбаченому цим Кодексом; 2) на підставах та в порядку, передбачених цим Кодексом, допускається тимчасове вилучення майна без судового рішення [3]. Відсилковий характер наведених норм зумовлює необхідність звернення до аналізу норм КПК України, присвячених врегулюванню випадків, за яких закон допускає обмеження права власності під час досудового розслідування кримінальних правопорушень, з метою визначення його поняття, кола процесуальних заходів, спрямованих на його здійснення, та підстав такого обмеження.

Аналіз останніх досліджень і публікацій

Проблематика обмеження та позбавлення права власності під час кримінального провадження за чинним КПК України була предметом дослідження широкого кола вітчизняних вчених. Так, до ії розкриття зверталися B.I. Галаган, I.В. Глов'юк, М.С. Городецька, С.О. Ковальчук, Г.М. Куцкір, Н.С. Моргун, О.В. Музиченко, С.М. Смоков, С.М. Тарасюк та інші науковці, які в переважній більшості досліджують підстави і порядок обмеження права власності під час проведення окремих слідчих (розшукових) дій або застосування окремих заходів забезпечення кримінального провадження та механізм позбавлення цього права на підставі судового рішення, у тому числі й у контексті практики Європейського суду з прав людини. Проте, комплексне дослідження поняття обмеження права власності у кримінальному провадженні, кола процесуальних заходів, спрямованих на його здійснення, та підстав обмеження зазначеного права у ході кримінального провадження в цілому та під час досудового розслідування, зокрема вченими, не проводилося.

Метою статті $є$ розкриття на основі норм КПК України обмежень права власності під час досудового розслідування кримінальних правопорушень. Необхідність досягнення цієї мети зумовлює потребу у вирішенні завдань, пов'язаних зі встановленням змісту поняття «обмеження права власності» в його кримінальному процесуальному розумінні, розкриттям встановлених законом обмежень цього права під час досудового розслідування та визначенням на основі цього підстав його обмеження.

\section{Виклад основного матеріалу}

Поняття «обмеження права власності» в доктрині кримінального процесу не знайшло однозначного розуміння. Так, Н.С. Моргун під обмеженням права власності розуміє об'єктивно сучасні обставини тимчасового характеру, що, позбавляючи власника можливості здійснювати свої окремі повноваження, звужують його свободу щодо здійснення дій над належним йому майном [4, с. 29]. Схоже визначення вказаного поняття наводитьO.В. Музиченко, на думку якого обмеженням права власності є передбачене законом тимчасове звуження можливості здійснення правомочностей власника, які полягають в обов'язку утримуватися від будь-яких дій або зазнавати дії з боку третіх осіб [5, с. 49]. Більш широко зазначене поняття розуміє Г.М. Куцкір, яка вказує, що обмеженням права власності у кримінальному провадженні 6 зовнішній вплив на суб’єктивне право власності конкретної особи, що втілюється у відповідні 


\section{Кримінальне право, кримінальний процес та криміналістика}

кримінальні процесуальні правовідносини 3 iї участю, тягне за собою виникнення певних правових труднощів, звуження, зменшення можливостей здійснення власником своїх повноважень і полягає у конкретних приписах власнику здійснити певні дії або утриматися від їх здійснення [6, с. 31].

Аналізуючи наведені визначення, потрібно зазначити, що вони характеризуються схожим змістом, закладеним у них вченими, але розкриваються за допомогою відмінних ознак. 3 урахуванням предмета кримінального процесуального права і зумовленої ним специфіки кримінальних процесуальних відносин, поняття «обмеження права власності» в його кримінальному процесуальному розумінні підлягає характеристиці за допомогою таких ознак: 1) воно є позбавленням власника можливості володіти, користуватися та розпоряджатися майном (без втрати ним цих правомочностей), внаслідок чого звужує його можливості стосовно реалізації права власності на належне йому майно; 2) обмеження права власності у кримінальному провадженні здійснюється у примусовому порядку; 3) види обмежень права власності чітко визначені нормами кримінального процесуального закону; 4) такі обмеження застосовується у кримінальному провадженні тільки з підстав і в порядку, встановлених законом; 5) обмеження права власності носять тимчасовий характер.

Як і поняття «обмеження права власності», коло слідчих (розшукових) дій і заходів забезпечення кримінального провадження, які призводять до його обмеження, в доктрині кримінального процесу визначається неоднозначно. Так, С.М. Смоков до числа заходів, які обмежують майнові права громадян під час здійснення кримінального провадження, відносить: накладення грошового стягнення, тимчасове вилучення майна й арешт майна, обгрунтовуючи свою позицію тим, що вказані заходи у ході їх застосування обмежують конституційні права громадян розпоряджатися вільно своїм майном, витрачаючи на свій розсуд зароблені кошти [7, с. 630]. Поділяючи наведену позицію, Н.С. Моргун вказує, що засада недоторканності права власності може суттєво обмежуватися також під час тимчасового доступу до речей і документів та їх вилучення, здійснення обшуку, огля- ду, а також проведення такої негласної слідчої (розшукової) дії, як обстеження публічно недоступних місць [4, с. 32]. Узагальнюючи наведені підходи, Г.М. Куцкір зазначає, що чинний КПК України передбачає позбавлення або обмеження права власності під час кримінального провадження у випадках: тимчасового доступу до речей і документів (глава 15), тимчасового вилучення майна (глава 16), арешту майна (глава 17), обшуку (стаття 234), огляду (стаття 237) [6, с. 31]. Схожу позицію відстоює М.С. Городецька, на думку якої, у кримінальному процесі право власності особи може бути обмежене такими шляхами: тимчасовий доступ з вилученням (виїмку), тимчасове вилучення (у разі затримання особи, під час обшуку речі, які не вказані в ухвалі про обшук як такі, що є предметом пошуку, речі, вилучені під час огляду), обшук (речі, які прямо вказані як предмет пошуку), арешт майна (усі тимчасово вилучені речі), добровільне надання речей або документів [8, с. 263]. Більш широко до визначення кола слідчих (розшукових) дій і заходів забезпечення кримінального провадження, пов'язаних з обмеженням права власності, підходить О.В. Музиченко, на думку якого, такими діями є: накладення грошового стягнення, застава, ізоляційні запобіжні заходи (у випадку залишення без нагляду майна підозрюваного, обвинуваченого), особиста порука, тимчасовий доступ до речей і документів (у випадку надання дозволу на вилучення речей і документів), тимчасове вилучення майна, арешт майна, обшук, огляд, обстеження публічно недоступних місць тощо $[5$, c. 45$]$.

Аналіз наведених позицій дозволяє стверджувати, що окремі з вказаних вченими слідчих (розшукових) дій і заходів забезпечення кримінального провадження не охоплюються поняттям «обмеження права власності», оскільки володіють іншою правовою природою та не відповідають його ознакам. Зокрема, це стосується висловлених вченими позицій у частині віднесення до їх числа накладення грошового стягнення та застосування запобіжних заходів. Так, відповідно до частини 1 статті 144 КПК України, грошове стягнення є заходом забезпечення кримінального провадження, який полягає у накладенні на учасників кримінального провадження штраф- 
них санкцій у грошовому вимірі у випадках та розмірах, передбачених КПК України, за невиконання процесуальних обов'язків [3]. Тобто за своєю правовою природою грошове стягнення $є$ кримінальною процесуальною санкцією, а тому не може розглядатися як обмеження права власності. У повному обсязі це стосується особистої поруки, яка з урахуванням частин 1 і 5 статті 180 КПК України є запобіжним заходом, що полягає у наданні письмового зобов'язання, невиконання поручителем якого призводить до накладення грошового стягнення. Що стосується застави, то недоцільність їі віднесення до числа заходів забезпечення кримінального провадження, які обмежують право власності, пояснюється тим, що вона на основі частин 1 і 2 статті 182 КПК України передбачає добровільне внесення коштів заставодавцем - підозрюваним, обвинуваченим або іншою фізичною чи юридичною особою. Внаслідок цього застава не відповідає ознаці обмеження права власності, яка передбачає його здійснення у кримінальному провадженні у примусовому порядку. Це стосується й добровільного надання речей або документів учасниками кримінального провадження, яке здійснюється в порядку частини 3 статті 93 КПК України, оскільки 3 огляду на факт добровільного надання таких речей і документів обмеження права власності у цьому випадку не відбувається, хоча їх подальше зберігання відповідно до частини 2 статті 100 КПК України здійснюється стороною кримінального провадження, якій вони надані [3]. Стосовно ізоляційних запобіжних заходів (у випадку залишення без нагляду майна підозрюваного, обвинуваченого) потрібно вказати, що внаслідок їх застосування позбавлення власника можливості володіти, користуватися та розпоряджатися майном відбувається внаслідок його затримання та тримання під вартою, а не внаслідок застосування до нього обмежень права власності у передбаченому законом порядку. Це свідчить про недоцільність віднесення ізоляційних запобіжних заходів у вказаних випадках до числа заходів забезпечення кримінального провадження, спрямованих на обмеження права власності, також у зв'язку з невідповідністю ознакам обмеження права власності.
Підстави обмеження права власності під час кримінального провадження у доктрині кримінального процесу прийнято класифікувати на дві групи: правові та фактичні. Так, В.I. Галаган і Н.С. Моргун зазначають, що під правовою підставою позбавлення або обмеження права власності у кримінальному провадженні слід розуміти як процесуальний документ, який надає слідчому, прокурору право провести процесуальну дію, під час чи за результатами якої можливе позбавлення або обмеження права власності, а фактичною підставою позбавлення й обмеження права власності є відомості, які надають можливість припустити, що проведення процесуальної дії, яке супроводжується позбавленням чи обмеженням права власності, надасть можливість отримати інформацію, яка має значення для розслідування [9, с. 76]. Поділяючи наведену позицію в цілому, потрібно вказати, що під час досудового розслідування правова підстава обмеження права власності відображає наявність формальної підстави для його здійснення внаслідок проведення відповідних слідчих (розшукових) дій або застосування відповідних заходів забезпечення кримінального провадження, а фактична - відображає наявність відомостей про факти, які вказують на передбачені законом підстави для їх проведення чи застосування.

Як основну правову підставу обмеження права власності у ході кримінального провадження частина 1 статті 16 КПК України визначає наявність вмотивованого судового рішення, ухваленого в порядку, передбаченому цим Кодексом [3]. Під час досудового розслідування таким судовим рішенням є ухвала слідчого судді, яка повинна відповідати вимогам частини 1 статті 16 КПК України, одна з яких стосується іiі змісту, а друга - порядку постановлення: 1) бути вмотивованою, тобто з урахуванням частини 6 статті 370 КПК України містити належні і достатні мотиви та підстави їі ухвалення; 2) бути ухваленою в порядку, передбаченому КПК України, тобто постановленою $з$ дотриманням вимог кримінального процесуального закону до порядку ініціювання, розгляду та вирішення відповідного питання.

Аналіз норм КПК України дозволяє стверджувати, що під час досудового розслідування ухвала слідчого судді $є$ правовою підставою об- 


\section{Кримінальне право, кримінальний процес та криміналістика}

меження права власності внаслідок проведення огляду, обшуку житла чи іншого володіння особи як слідчих (розшукових) дій, обстеження публічно недоступних місць як негласної слідчої (розшукової) дії, тимчасового доступу до речей і документів із здійсненням їх вилучення (виїмки) та арешту майна як заходів забезпечення кримінального провадження та затримання на підставі ухвали слідчого судді як тимчасового запобіжного заходу.

Проведення огляду, обшуку (за винятком огляду, обшуку житла або іншого володіння особи) здійснюється без ухвали слідчого судді, так само, як і законне затримання за ії відсутності. У цих випадках правовою підставою обмеження права власності є: 1) протокол огляду, обшуку, під час якого здійснювалося тимчасове вилучення майна; 2) протокол затримання, в ході якого здійснювалося тимчасове вилучення майна. При цьому, як вказуєС.О. Ковальчук, вилучені під час обшуку речі, які не входять до переліку, щодо якого прямо надано дозвіл на відшукання в ухвалі про дозвіл на проведення обшуку, та вилучені під час обшуку та огляду речі, що не відносяться до предметів, які вилучені законом з обігу, вважаються тимчасово вилученим майном [10, с. 242]. 3 урахуванням вимоги кримінального процесуального закону щодо обов'язковості здійснення судового контролю за обмеженням права власності, тимчасове вилучення майна триває до накладення на нього арешту на підставі ухвали слідчого судді або до його повернення особі, у якої воно було вилучено, за постановою прокурора або ухвалою слідчого судді з підстав і в порядку, встановлених статтею 169 КПК України.

Фактичні підстави обмеження права власності під час досудового розслідування кримінальним процесуальним законом диференціюються залежно від виду слідчих (розшукових) дій або заходів забезпечення кримінального провадження, які підлягають проведенню або застосуванню у кримінальному провадженні та можуть призвести до обмеження зазначеного права.

\section{Висновки}

Проведене дослідження свідчить, що обмеження права власності в кримінальному провадженні є встановленими нормами КПК
України умовами примусового позбавлення власника можливості володіти, користуватися та розпоряджатися майном (без втрати ним цих правомочностей), які носять тимчасовий характер і застосовується з підстав і в порядку, встановлених законом.

До числа слідчих (розшукових) дій і заходів забезпечення кримінального провадження, які призводять до обмеження права власності, доцільно віднести: 1) огляд, обшук, під час якого здійснюється тимчасове вилучення майна; 2) затримання, в ході якого здійснюється тимчасове вилучення майна; 3) тимчасовий доступ до речей і документів із здійсненням їх вилучення (виїмки); 4) арешт майна;5) обстеження публічно недоступних місць як негласної слідчої (розшукової) дії.

Підстави обмеження права власності під час кримінального провадження у доктрині кримінального процесу прийнято класифікувати на дві групи: 1) правові - наявність формальної підстави для його здійснення внаслідок проведення відповідних слідчих (розшукових) дій або застосування відповідних заходів забезпечення кримінального провадження; 2) фактичні - наявність відомостей про факти, які вказують на передбачені законом підстави для їх проведення чи застосування.

\section{Мiтература}

1. Конституція України від 28 червня 1996 року. URL: https://zakon.rada.gov.ua/laws/ show/254\%D0\%BA/96-\%D0\%B2\%D1\%80.

2. Перший протокол від 20 березня 1952 року до Конвенції про захист прав людини i основоположних свобод. URL: http://zakon. rada.gov.ua/laws/show/994_535.

3. Кримінальний процесуальний кодекс України від 13 квітня 2012 року № 4651-VI. URL: https://zakon.rada.gov.ua/laws/show/465117.

4. Моргун Н.С. Обмеження права власності при реалізації засади недоторканності права власності у кримінальному провадженні. Юридична наука. 2014. № 6. С. 27-34.

5. Музиченко О.В. Реалізація конституційного принципу недоторканності права власності на стадії досудового розслідування: дис. ... канд. юрид. наук: 12.00.09. Х., 2016. 267 с.

6. Куцкір Г.М. Засада недоторканності права власності: поняття, зміст і реалізація у 


\section{АНОТАЦІЯ}

Стаття присвячена розкриттю на основі норм Кримінального прочесуального кодексу Украйни обмежень права власності під час досудового розслідування кримінальних правопорушень.

Досліджено сбормовані в доктрині кримінального процесу визначення поняття «обмеження права власності», у результаті аналізу яких наведено авторсъкий підхід до виокремлення ознак, якими воно характеризується. Проаналізовано теоретичні підходи до визначення кола слідчих (розшукових) дій $i$ заходів забезпечення кримінального провадження, які призводять до обмеження права власності під час досудового розслідування. Підтримано позицію про доцільність здійснення класифікациї підстав обмеження права власності під час кримінального провадження на дві групи: правові та фактичні. 3 урахуванням норм Кримінального прочесуального кодексу Украӥни розкрито вимоги до ухвали слідчого судді як основної правової підстави обмеження иъього права в ході досудового розслідування, вказано на випадки ї постановлення, а також визначено інші правові підстави обмеження права власності в зазначеній стадї кримінального провадження. Вказано на залежність бактичних підстав обмеження ивого права від виду слідчих (розшукових) дій або заходів забезпечення кримінального провадження, які підлягають проведенню або застосуванню у кримінальному провадженні.

За результатами дослідження визначено поняття «обмеження права власності» в його кримінальному процесуальному розумінні, узагальнено встановлені законом обмеження иъого права під час досудового розслідування та визначено поняття правових $і$ фбактичних підстав його здійснення.

Ключові слова: засади кримінального провадження, недоторканність права власності, обмеження права власності, досудове розслідування, ухвала слідчого судді, протокол.

кримінальному провадженні: дис. ... канд. юрид. наук: 12.00.09. Одеса, 2014. 272 с.

7. Смоков С.М. Види обмежень конституційних прав громадян у новому Кримінальному процесуальному кодексі України. Форум права. 2012. № 2. С. 628-632.

8. Городецька М. Окремі питання обмеження права на власність під час проваджен-

\section{SUMMARY}

The article is devoted to determining the restrictions of the property rights during the pre-trial investigation of criminal offenses on the basis of norms of the Criminal Procedure Code of Ukraine.

The definitions of the concept of «restriction of the property rights» formed in the doctrine of criminal process are investigated, as a result of the analysis of which the author's approach to allocation of signs by which it is characterized is induced. Theoretical approaches to determining the range of investigative (search) actions and measures to ensure criminal proceedings, which lead to the restriction of property rights during the pre-trial investigation, are analyzed. The position on expediency of classification of the bases of restriction of the property rights during criminal proceedings on two groups, legal and factual, is supported. Taking into account the norms of the Criminal Procedure Code of Ukraine, the requirements for the decision of the investigating judge as the main legal basis for restricting this right during the pre-trial investigation are revealed, cases of its ruling are indicated, and other legal grounds for restricting property rights at this stage of criminal proceedings are identified. The dependence of the factual grounds for restricting this right on the type of investigative (search) actions or measures to ensure criminal proceedings, which are subject to conduct or application in criminal proceedings, is indicated.

On the results of the research the concept of «restriction of property rights» in its criminal procedural sense is defined, the statutory restrictions on this right during the pre-trial investigation are summarized and the concept of legal and factual grounds for its implementation are defined.

Key words: principles of criminal proceedings, inviolability of property rights, restriction of property rights, pre-trial investigation, decision of the investigating judge, record.

ня обшуку. Підриємнищтво, господарство, право. 2017. № 12. С. 263-267.

9. Галаган B.I., Моргун Н.С. Недоторканність права власності як засада кримінального провадження на досудовому розслідуванні: монографія. К., 2017. 185 с.

10. Ковальчук С.О. Вчення про речові докази у кримінальному процесі: теоретикоправові та практичні основи: монографія. Івано-Франківськ: Супрун В.П., 2017. 618 с. 